Chirurgia (2020) 115: 63-68

No. 1, January - February

Copyright@ Celsius

http://dx.doi.org/10.21614/chirurgia.115.1.63

\title{
Morbidity of Retrograde Flexible Ureteral Approach for Pyelo-Caliceal Stones - A Retrospective Review of 4500 Procedures
}

\author{
Petrișor Aurelian Geavlete, Răzvan Mulțescu, Bogdan Florin Geavlete \\ "Saint John" Emergency Clinical Hospital, Department of Urology, Bucharest Romania \\ Sanador Hospital, Bucharest Romania
}

Corresponding author:

Razvan Multescu, MD

"Saint John" Emergency Clinical Hospital

Department of Urology

Vitan Barzesti 13, 042122, sector 4

Bucharest, Romania

Sanador Hospital, Sevastopol 9

Bucharest Romania

E-mail: razvanmultescu@yahoo.com
Received: 14.10 .2019

Accepted: 20.11 .2019

\section{Rezumat}

Morbiditatea asociată abordului ureteroscopic flexibil retrograd pentru calculi pielo-caliceali - un studiu retrospectiv pe 4500 proceduri

Introducere: Abordul ureteroscopic flexibil retrograd este o procedură eficientă şi relativ sigură. Scopul studiului a fost evaluarea retrospectivă pe un număr semnificativ de cazuri a siguranței abordului ureteroscopic flexibil retrograd la pacienții cu litiază pielo-caliceală.

Material si Metodă: Am evaluat retrospectiv 4500 ureteroscopii flexibile retrograde efectuate în două centre medicale. Complicațiile asociate acestui tip de abord au fost identificate retrospective şi stratificate conform clasificării Clavien-Dindo.

Rezultate: Incidentele intraoperatorii au fost identificate în 5,2\% din proceduri. Complicațiile au survenit în $18,9 \%$ din proceduri. Două treimi au fost complicații septic, teaca de acces ureteral dovedindu-se un factor de protectie împotriva acestora. Majoritatea complicațiilor au fost uşoare. In $4,8 \%$ din cazurile în care a fost utilizată teaca de acces ureteral au survenit leziuni de perete ureteral gradul 2 şi 3.

Concluzii: Majoritatea complicațiilor associate abordului ureteroscopic flexibil retrograd sunt uşoare, indiferent de tipul ureteroscopului utilizat. Presiunea redusă la nivelul sistemului pielocaliceal este importantă pentru menținerea ratei complicațiilor (atât septice cât şi non-septice) cât mai mică.

Cuvinte cheie: complicații, ureteroscopie flexibilă, septic, teacă de acces ureteral 


\section{Abstract}

Introduction: The retrograde flexible ureteroscopic approach is an effective and relatively safe procedure. The aim of this study was to retrospectively evaluate the safety of retrograde flexible ureteroscopic approach in patients with pyelo-caliceal stones on a significant number of cases.

Material and method: We retrospectively evaluated 4500 procedures of flexible retrograde ureteroscopic approach for pyelocaliceal lithiasis, operated in two centers. The complications associated with this approach were retrospectively evaluated and data was stratified according to ClavienDindo classification.

Results: Intraoperative incidents occurred during 5.2\% of the procedures. Overall complications occurred in $18.9 \%$ of the procedures. Around two thirds of them were septic complications, the use of ureteral access sheath proving to be a protective factor against them. Most of the complications were mild. In $4.8 \%$ of the cases in which ureteral access sheath was used, we encountered grade 2 and 3 ureteral wall lesions.

Conclusions: Most of the complications associated with retrograde flexible ureteroscopic approach are mild, regardless the type of flexible ureteroscope used. Reduced pressure in the pyelo-caliceal system is important to maintain the complications rate low, both septic and non-septic.

Key words: complications, flexible ureteroscopy, septic, ureteral access sheath

\section{Introduction}

Nowadays, the retrograde flexible ureteroscopic approach is an effective and relatively safe procedure, especially for the treatment of pyelo-caliceal stones. In the beginning of the 80', Bagley, Lyon and Huffman created the modern type of the flexible ureteroscope by adding three very distinctive features: the deflection mechanism, the working channel and the irrigation system (1). Since then, the constant technological progress (certain materials, lasers, video chips) made possible the development of new generations of such devices, each aiming to improve the efficacy of the procedure, to prolong the life span of the instruments and to decrease the associated morbidity.

The aim of this study was to retrospectively evaluate the safety of retrograde flexible ureteroscopic approach in patients with pyelocaliceal stones on a significant number of cases and using a wide range of flexible ureteroscopes.

\section{Material and Method}

We retrospectively evaluated 4500 retrograde flexible ureteroscopic procedures for pyelocaliceal lithiasis, performed in two centres, "Saint John" Emergency Clinical Hospital and Sanador Hospital between 2001 and 2019.

The procedures were performed by three surgeons, and involved 7 types of reusable flexible ureteroscopes (Storz 11274AA - 470 procedures, Storx Flex-X - 382 procedures, Storx Flex-Xc - 1021 procedures, Wolf Cobra 68 procedures, Olympus URF-P5 - 298 procedures, Olympus URF-V - 673 procedures, Olympus URF-V2 - 1576 procedures) and one type of single use ureteroscope (Pusen - 12 procedures). To achieve stone fragmentation (when necessary) we used electro-hydraulic lithotripsy (in a reduced number of cases) or Ho:YAG lithotripsy (in most of the cases).

Ureteral access sheath was used every time multiple ureteral passages or prolonged lithotripsy time in the pyelo-caliceal system were anticipated.

Indwelling of a JJ stent at the end of the procedure was performed if the ureteral access and passage created the need for it, if the procedural time was significant or if restant stone fragments were still present.

The incidents and complications associated with this approach were retrospectively 
evaluated and data was stratified according to Clavien-Dindo classification (2). Septic and non-septic complications were analysed in two different groups. Minor lesions of the upper urinary tract wall (Fig. 1) without any symptoms were not classified as complications.

Influence of various instruments (flexible ureteroscopes, ureteral access sheath) over the morbidity of the procedure was also determined. The lesions of the ureter and renal pelvis associated with the ureteral acces sheath use, were stratified according to the classification proposed by Traxer and Thomas (3). Only lesions of at least grade 3 (complete perforation of the ureteral wall with exposure of the periureteral fat) were considered as complications.

\section{Results}

In 2223 patients a single procedure, in 557 patients two procedures, in 309 patients three procedures and in 59 patients four procedures were performed.

Intraoperative incidents occurred during $5.1 \%$ of the procedures. Most of them were instrumental damage $(4.2 \%)$, followed by stone fragments migration in positions impossible to access using the available flexible ureteroscope $(0.9 \%)$.

Overall complications occurred in $18.9 \%$ of the procedures.

Septic complications (ranging from fever to septic shock) occurred in $12.1 \%$ of the procedures, most of them being mild. In this complications category, $69 \%$ were Clavien II, 16\% Clavien IIa, 10\% Clavien IVa and 5\% Clavien IVb. Mortality was $0 \%$ in this group. $51.9 \%$ of the septic patients were pre-stented, and only $25 \%$ of them were operated using a ureteral access sheath.

In $6.8 \%$ of the cases non-septic complications (severe upper urinary tract wall lesions Fig. 2, postoperative pain, persistent hematuria, liquid retroperitoneal extravasation, intrarenal or subcapsular hematoma) were encountered. Clavien I and II occurred in $81 \%$, Clavien III in $9 \%$ and Clavien IV in $1 \%$ of the cases. No Clavien V cases were encountered in

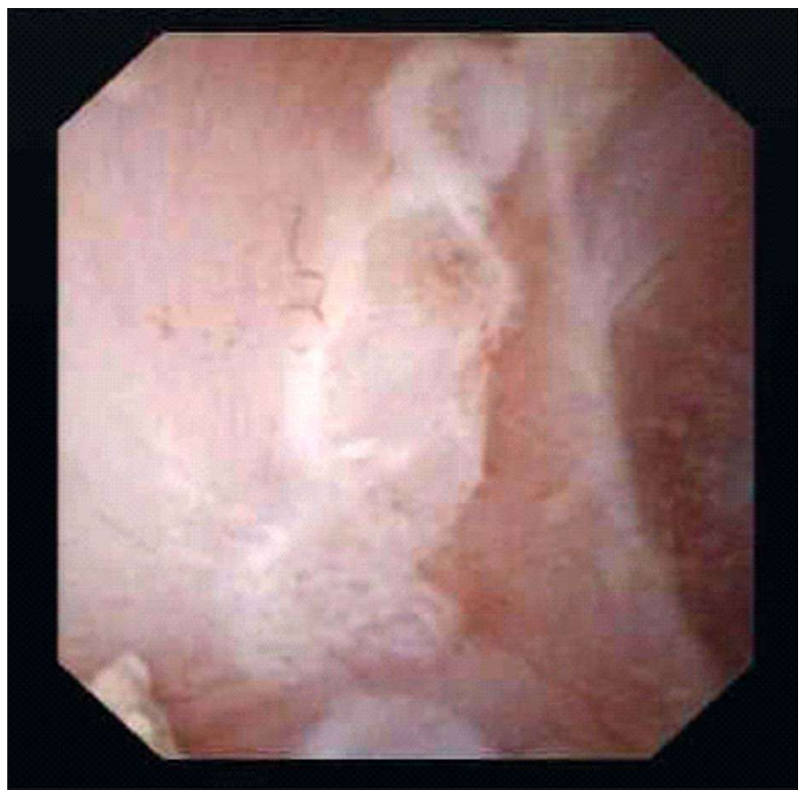

Figure 1. Superficial mucosal lesions secondary to laser lithotripsy

this group either. Ureteral access sheath was used in $78 \%$ of the non-septic complications group.

In 22 cases intraparenchimatous (5 cases) or subcapsular hematoma (18 cases) were diagnosed during the postoperative period, while 3 cases presented massive liquid extravasation of the fluid in the retroperitoneum. Among these cases, 4 occurred in

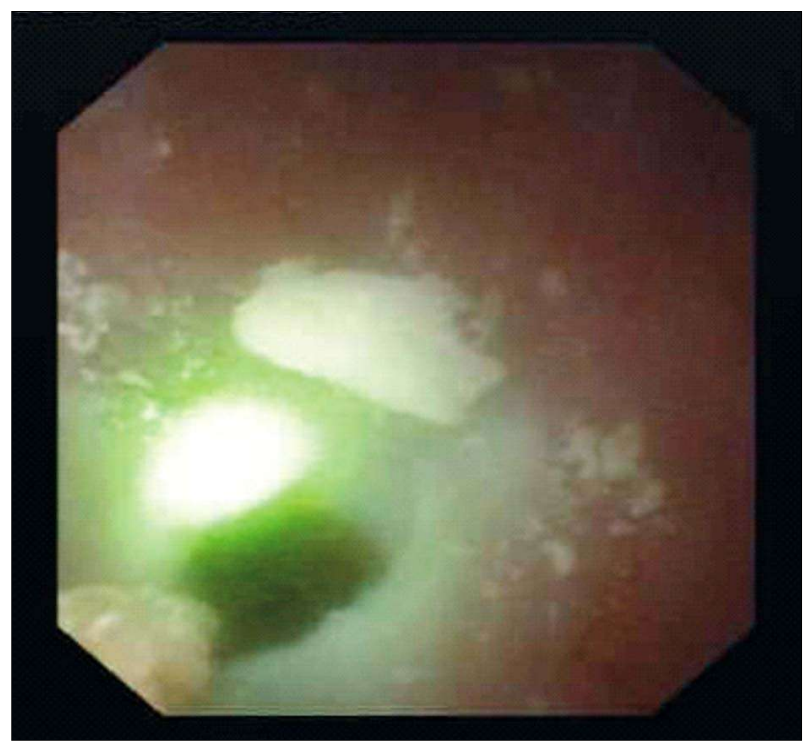

Figure 2. Laser perforation of the pyelic wall 
cases treated using a Storz Flex-Xc flexible ureteroscope, 2 in cases treated using an Olympus URF-V2 flexible ureteroscope and 18 cases in patients treated using a Olympus URF-V flexible ureteroscope.

Regarding the use of ureteral access sheath, in $4.8 \%$ of the cases we encountered grade 2 and 3 ureteral wall injuries according to the classification proposed by Traxer and Thomas.

\section{Discussion}

Intraoperative incidents in our study were represented mostly by intrumental damage (Fig. 3). A recent study by Ozimek et al, a steep angle between the axis of the renal pelvis and the axis of the lower calyx were demonstrated as a risk factor for both endoscope damage and perioperative morbidity (4).

Most of the complications associated with retrograde flexible ureteroscopic approach are mild. In study of flexible ureteroscopy under local anesthetic, Pai et al didn't encounter any complications above Clavien II (5).

Two thirds of the complications encountered in our study were septic. Various precautions to reduce the risk of such complications were proposed by different authors. Baboudjian et al identified as predictive factors for septic complications the female gender, presence UTI before the procedure, especially with preoperative polymicrobial urine cultures, and prolonged operative time. Consequently, beside the usual precautions of microbiological urine testing and UTI treatment before the procedure, the limitation of the intervention time was also one of such proposals (6).

Single use flexible ureteroscopes may also reduce the cross-infection risk by eliminating the sterilization requirements, but it will not influence the dangers associated with the presence of germs in urine or into the stone itself $(7,8)$. As demonstrated by various authors $(9,10)$ and also confirmed in our study, the use of ureteral access sheath proved to be a protective factor for septic complications, most probably by maintaining a reduced pressure inside the collecting system.

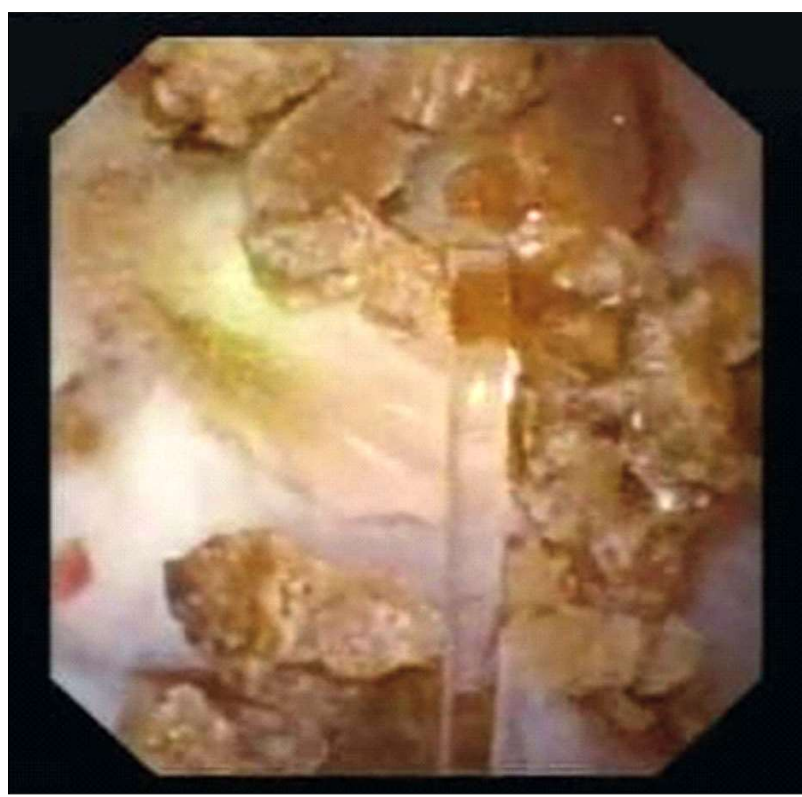

Figure 3. Distal part of a broken laser fiber

One of the interesting findings of the study was the fact the majority of the cases with massive fluid extravasation in the retroperitoneum, and of intrarenal or subcapsular hematoma occurred in patients in which the Olympus URF-V endoscope was used. Such complications are rarely reported in the literature $(11,12)$ and management is usually conservative. In selected cases it may require angiography, embolisation or even removal of the blood clot by open surgery (12).

Watanabe et al speculates that these complications may occur after either creating perforations of the collecting system during laser lithotripsy or secondary to increased pressure in the collecting system (13) while Chiu suggests that thin parenchyma adjacent to the calices may increase the risk (12). In our series, no significant lesions of the collecting system were recorded. The fact that in the majority of these cases a Olympus URF-V flexible ureteroscope was used, suggests that probably the increased pressure theory is the most probable cause. Despite the fact that it has a working channel similar with other models, URF-V is the endoscope with the largest diameter at the tip. So, although the irrigation flux is probably similar by comparison to other models, by occupying a larger 
volume in the ureter or the ureteral access sheath, this flexible ureteroscope is associated with a reduced back-flow of the fluid and thus with an increased pressure in the pyelocaliceal system. Of course, other anatomic and functional factors may be involved. However, technological progress allowed all the newer models to have an outer diameter smaller than it, reducing the risk of such complication.

Ureteral access sheath, as a part of flexible ureteroscopic procedures, is associated with a specific category of complications. Traxer and Thomas proposed a severity scale to classify such complications (3).

In our study, ureteral wall injuries including mucosa and smooth muscle but with adventitial preservation (grade 2) and ureteral wall perforation with adventitial perforation and exposure of periureteral fat (grade $3-$ Fig. (d) were encountered in a rather limited number of cases, conservative measures being sufficient in all of them. In our experience, insertion of ureteral access sheath using only a reasonable amount of push force is essential in order to prevent severe ureteral wall lesions. If insertion is not possible in such conditions, JJ stenting and attempt of flexible ureteroscopy in another setting is recommended. Also, extraction of the ureteral access sheath en bloc with the ureteroscope and visual inspection of the ureter is mandatory in order to identify and treat such lesions in real time.

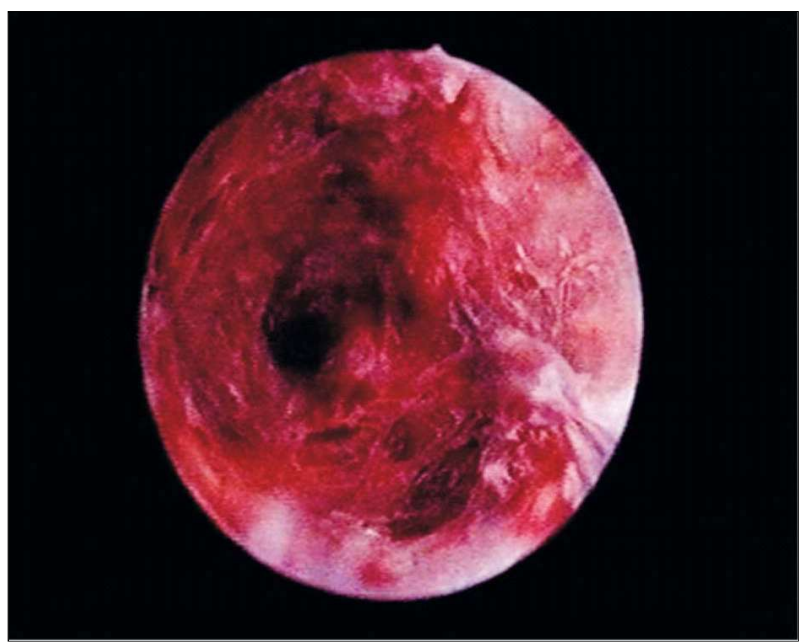

Figure 4. Ureteral wall lesions secondary to ureteral access sheath insertion

\section{Conclusions}

Most of the complications associated with retrograde flexible ureteroscopic approach are mild, regardless the type of flexible ureteroscope used.

Using large diameter flexible ureteroscopes seem to be associated with an increased risk of intrarenal or subcapsular hematoma and fluid extravasation in the retroperitoneum.

Reduced pressure in the pyelo-caliceal system is important to maintain the complications rate low, both septic and non-septic.

\section{Conflict of Interest}

The authors declare no conflicts of interests.

\section{References}

1. Bagley DH, Huffman JL, Lyon ES. Combined rigid and flexible ureteropyeloscopy. J Urol. 1983;130(2):243-4

2. Clavien PA, Barkun J, de Oliveira ML, Vauthey JN, Dindo D, Schulick RD, et al. The Clavien-Dindo classification of surgical complications: five-year experience. Ann Surg. 2009;250(2): 187-96.

3. Traxer 0, Thomas A. Prospective evaluation and classification of ureteral wall injuries resulting from insertion of a ureteral access sheath during retrograde intrarenal surgery. J Urol. 2013;189(2): 580-4. Epub 2012 Oct 8

4. Ozimek T, Cordes J, Wiessmeyer JR, Schneider MH, Hupe MC, Gilbert N, et al. Steep infundibulopelvic angle as a new risk factor for flexible ureteroscope damage and complicated postoperative course. J Endourol. 2018;32(7):597-602.

5. Pai A, Kadhim H, Mackie S, Watson G. Local anesthetic flexible ureterorenoscopy in the management of urolithiasis. J Endourol. 2019;33(9):696-698. Epub 2019 Jun 20

6. Baboudjian M, Gondran-Tellier B, Abdallah R, Sichez PC, Akiki A, Gaillet $S$, et al. Predictive risk factors of urinary tract infection following flexible ureteroscopy despite preoperative precautions to avoid infectious complications. World J Urol. 2019 Jul 29. (Epub ahead of print)

7. Bai $T, Y u X$, Qin $C, X u T$, Shen $H$, Wang $L$, et al. Identification of Factors Associated with Postoperative Urosepsis after Ureteroscopy with Holmium: Yttrium-Aluminum-Garnet Laser Lithotripsy. Urol Int. 2019 Aug 28:1-7. (Epub ahead of print),

8. Mager R, Kurosch M, Höfner T, Frees S, Haferkamp A, Neisius A. Clinical outcomes and costs of reusable and single-use flexible ureterorenoscopes: a prospective cohort study. Urolithiasis. 2018; 46(6):587-593. Epub 2018 Jan 22

9. Osther PJS. Risks of flexible ureterorenoscopy: pathophysiology and prevention. Urolithiasis. 2018;46(1):59-67. Epub 2017 Nov 18

10. Auge BK, Pietrow PK, Lallas CD, Raj GV, Santa-Cruz RW, Preminger 
GM. Ureteral access sheath provides protection against elevated renal pressures during routine flexible ureteroscopic stone manipulation. J Endourol. 2004;18(1):33-6

11. Paiva MM, da Silva RD, Jaworski P, Kim FJ, Molina WR. Subcapsular hematoma after ureteroscopy and laser lithotripsy. Can J Urol. 2016;23(4):8385-7
12. Chiu PK, Chan CK, Ma WK, To KC, Cheung FK, Yiu MK. Subcapsular hematoma after ureteroscopy and laser lithotripsy. J Endourol. 2013;27(9):1115-9

13. Watanabe R, Inada K, Azuma K, Yamashita Y, Oka A. Case of renal subcapsular hematoma caused by flexible transurethral lithotripsy. Hinyokika Kiyo. 2013;59(9):565-8 